DEVELOPING WATER CYCLE STAGE MEDIA FOR SCIENCE LEARNING AT GRADE V

\author{
Annisa Wijariyah $^{1}$, A Syachruroji ${ }^{2}$, Nana Hendracipta ${ }^{3}$ \\ 1,2,3 Universitas Sultan Ageng Tirtayasa, Indonesia \\ Iannisa.wijariyah21@yahoo.co.id, ${ }^{2}$ ahmadsyachruroji@untirta.ac.id, ${ }^{3}$ nanahendracipta@untirta.ac.id
}

\title{
PENGEMBANGAN MEDIA PEMBELAJARAN PANGGUNG SIKLUS HIDROLOGI PADA MATA PELAJARAN IPA DI KELAS V
}

\section{ARTICLE INFO}

Submitted:

09 September 2020

$09^{\text {th }}$ September 2020

Accepted:

03 Oktober 2020

$03^{\text {nd }}$ October 2020

Published:

25 Desember 2020

$25^{\text {th }}$ December 2020

\section{ABSTRACT}

\begin{abstract}
This study aimed to reveal how to develop the water cycle stage media for science learning at grade $V$, to analyze the feasibility of water cycle stage media developed for science learning at grade $V$, and to reveal the students' response to the water cycle stage learning media. This study was conducted at SDN Teras 1. The subjects of this study were 20 students at grade V SDN Teras 1, in which 15 students were on a limited trial. This study was conducted based on Borg and Gall model modified by Sugiyono. This model included six stages: namely problem analysis, data collection, product design, design validation, design revision, and product testing. The instruments in this study were questionnaire sheets which were addressed for the lecturer and students. Based on the result of data analysis, it was found that the quality of the water cycle stage media was presented in three categories. First, the feasibility of water cycle media from the media experts was categorized as very feasible with a percentage of $91.3 \%$. Then, according to the material experts, this media was alo categorized as very feasible with a percentage of $93 \%$. Finally, the feasibility result from education experts was also categorized as very feasible with a percentage of $93 \%$. In addition, after conducting the trial to 15 students, the result of the students' response to the water cycle stage media was $89 \%$, which was also in the very feasible category.
\end{abstract}

Keywords: developing learning media, water cycle media, water cycle stage, science learning media, three dimensional media

Abstrak: Penelitian ini bertujuan untuk mengetahui cara mengembangkan media pembelajaran panggung siklus hidrologi pada mata pelajaran IPA di kelas V, untuk mengetahui kelayakan media pembelajaran panggung siklus hidrologi yang dikembangkan, dan untuk mengetahui respons siswa terhadap media pembelajaran panggung siklus hidrologi. Penelitian ini dilakukan di SDN Teras 1 dengan subjek penelitian siswa kelas $V$ sejumlah 20 orang dengan rincian 15 orang pada uji coba terbatas. Jenis penelitian ini mengacu pada model Borg and Gall yang dimodifikasi oleh Sugiyono. Model ini terdiri dari enam tahap yaitu analisis masalah, pengumpulan data, desain produk, validasi desain, revisi desain dan uji coba produk. Instrumen yang digunakan berupa lembar angket untuk validasi media oleh dosen dan lembar angket siswa. Berdasarkan analisis data dapat disimpulkan kualitas panggung siklus hidrologi yang dikembangkan termasuk kategori sangat layak dengan persentase $91,3 \%$ dari dua ahli media, kategori sangat layak dengan persentase $93 \%$ dari dua ahli materi, dan $93 \%$ dari dua ahli pendidikan. Respons siswa terhadap media pembelajaran panggung siklus hidrologi pada uji coba dengan 15 responden sebesar 89\% dengan kategori sangat layak.

Kata kunci: pengembangan media pembelajaran, media siklus air, panggung siklus hidrologi, media pembelajaran IPA, media tiga dimensi.

CITATION

Wijariyah, A., A Syachruroji, \& Hendracipta, N. (2020). Developing Water Cycle Stage Media for Science Learning at Grade V. Primary: Jurnal Pendidikan Guru Sekolah Dasar, 9(6), 765-775. DOI: http://dx.doi.org/10.33578/jpfkip.v9i6.8049. 


\section{PENDAHULUAN}

Media pembelajaran dapat diartikan sebagai sebuah bahan atau alat bantu saat guru mengajar atau sedang melakukan proses belajar mengajar di kelas. Media pembelajaran sangat penting bagi guru yang akan melakukan proses belajar mengajar, meskipun tidak $100 \%$ media pembelajaran membantu guru akan tetapi media pembelajaran sangat efesien untuk dibuat atau dikembangkan. Menurut Basri \& Rusdiana (2015:124), media merupakan alat yang mempunyai kegunaan memberikan pesan. Media juga bentuk jamak dari kata "medium" yang berasal dari bahasa latin yang secara harfiah berarti perantara atau pengantar.

Sedangkan menurut Indriana (2011:15) menjelaskan bahwa media sebagai alat bantu yang sangat bermanfaat bagi para siswa dan pendidik dalam proses belajar dan mengajar. digunakan oleh siswa. Sama halnya dengan apa yang dikemukakan oleh Sanaky (2015:3) media pembelajaran merupakan sebuah alat yang berguna dan dapat dimanfaatkan untuk menyampaikan informasi tentang pembelajaran.

Pernyataan di atas dapat meyakinkan bahwa dalam proses pembelajaran guru tidak hanya mengajar tanpa membawa alat dan bahan ajar, tetapi guru juga perlu membawa sebuah media pembelajaran untuk membantu proses pembelajaran atau memudahkan siswa dalam memahami pembelajaran. Dalam proses pembelajaran guru sebagai fasilitator yang berkewajiban memfasilitasi siswa, dengan begitu siswa dapat mengembangkan kreasinya, dengan media pembelajaran siswa dapat mengembangkan daya ingat melalui macam-macam media pembelajaran.

Harapan di atas, pada kenyataannya belum sepenuhnya terwujud dalam pelaksanaan di sekolah. Berdasarkan observasi dan wawancara yang peneliti lakukan di kelas V SDN Teras 1, Kab. Serang, permasalahan dalam proses pembelajaran di kelas tersebut yaitu kurangnya memahami konsep siklus air atau siklus hidrologi dan pada keterangannya bahwa selama ini pembelajaran dan materi tersebut masih masih terpaku pada buku dan kurang memanfaatkan lingkungan sekitar maupun benda-benda yang dapat disajikan sebagai media pembelajaran. Selain itu, metode yang diterapkan oleh guru juga belum bervariasi masih dengan alur monoton, guru juga belum bisa memanfaatkan alat peraga yang dapat dikreasikan, alat peraga yang guru perlihatkan hanya gambar biasa dan tidak berbentuk seperti nyata.

Menurut Arief (Kustadi \& Sutjipto, 2011:5) pembelajaran, siswa sebagai orang yang belajar dan guru sebagai orang yang mengajar. Sama halnya dengan apa yang dikemukakan sebelumnya, menurut Sanaky (2015:3) pembelajaran merupakan proses interaksi antara siswa, guru, dan bahan ajar.

Sedangkan menurut Wisudawati \& Sulistyowati (2014:22) IPA ialah rumpun ilmu, memiliki karakteristik khusus, yaitu mempelajari fenomena alam yang faktual (Factual), baik berupa kenyataan (Reality) atau kejadian (Events) dan hubungan sebab-akibatnya. Cabang ilmu yang termasuk anggota rumpun IPA saat ini antara lain Biologi, Fisika, IPA, Astronomi/ Astrofisika, dan Geologi.

Jadi dapat disimpulkan dari para ahli di atas bahwa pembelajaran IPA merupakan guru dan siswa yang mempelajari sebuah ilmu yang di dalamnya terdapat fenomena factual, baik dalam kehidupan nyata maupun kejadian dan hubungan sebab-akibatnya.

Panggung Siklus Hidrologi ini sendiri tergolong pada kategori media berbasis visual berbentuk tiga dimensi, yang di dalamnya terdapat diorama mengenai materi proses siklus air pada kelas V sekolah dasar. Media visual berarti media yang mempergunakan mata sebagai alat indera manusia dalam kegiatan mengamati dan mengidentifikasi, media tiga dimensi ialah sesuatu yang bisa terlihat dari segala arah, yang alangkah baiknya dibuat dengan ukuran yang sesuai dengan kebutuhan atau lebih besar, mempunyai dimensi panjang, lebar, dan tinggi atau ketebalan dari bahan media tersebut. Sedangkan diorama mencakup dari kedua sifat di atas, sifat visual serta tiga dimensi bergabung menjadi satu kesatuan berbentuk diorama, diorama panggung siklus hidrologi sendiri ialah menggambarkan atau memperagakan scane tiga dimensi dari suatu 


\section{PRIMARY : JURNAL PENDIDIKAN GURU SEKOLAH DASAR \\ VOLUME 9 NOMOR 6 DESEMBER 2020}

ISSN: 2303-1514 | E-ISSN: 2598-5949

Jurnal Pendidikan Guru Sekolah Dasar

DOI : http://dx.doi.org/10.33578/jpfkip.v9i6.8049

https://primary.ejournal.unri.ac.id/index.php/JPFKIP

keadaan dalam ukuran minimalisnya. Dalam scane tersebut terdapat pemandangan yang melukiskan bagaimana proses terjadinya siklus air.

Media yang akan dibuat berupa panggung yang terdapat benda-bendanya berbentuk tiga dimensi, karena akan lebih memudahkan konsep pemahaman siswa setelah melakukan pengamatan pada hal-hal yang mendekati sifat konkret. Berikut ini penjelasan para ahli mengenai media pembelajaran visual berbasis tiga dimensi dalam sebuah diorama yang akan diterapkan pada panggung siklus hidrologi:

Menurut Sadiman (2011:28) menerangkan yakni media visual merupakan media untuk mengungkapkan informasi sumber ke penerima informasi. Saluran yang dipergunakan melibatkan indera penglihatan. Informasi yang akan disampaikan dicurahkan ke dalam simbol-simbol komunikasi.

Jadi kesimpulannya, bahwa media tiga dimensi dominan objek yang dipakai ialah media yang bentuknya dapat diamati dari berbagai arah dan sebuah tiruan beberapa objek nyata yang diketahui sangat besar, sangat jauh, sangat kecil, sangat mahal, sangat jarang ditemui, atau terlalu sulit saat guru akan membawa media tersebut ke sekolah.

Menurut Sudjana \& Rivai (2013:170) media diorama berupa sebuah pemandangan tiga dimensi mini bertujuan untuk penggambaran pemandangan yang sebenarnya.

Berbeda halnya dengan apa yang dikemukakan oleh Prastowo (2015:236) mengungkapkan diorama berupa sesuatu yang di dalamnya terdapat komponen-komponen sosok atau objek-objek ditempatkan di panggung yang berlatar belakang pemandangan atau sebagainya yang disesuaikan dengan penyampaian.

Berdasarkan beberapa penjelasan dari ahli di atas, dapat disimpulkan bahwasannya media diorama adalah pemandangan alam atau suatu objek yang dituangkan ke dalam bentuk ukuran kecil di dalamnya terdapat komponen-komponen objek yang diperkecil juga.

Berdasarkan uraian yang telah dipaparkan sebelumnya, maka dalam penelitian ini bertujuan untuk mengetahui proses dalam mengembangkan alat peraga panggung siklus hidrologi, untuk mengetahui kelayakan media tersebut dan juga agar dapat mengetahui respon siswa setelah belajar menggunakan media tersebut.

\section{METODE PENELITIAN}

Penelitian ini menggunakan metode penelitian dan pengembangan (Reserch And Development dengan tujuan untuk menghasilkan produk media pembelajaran berupa panggung

siklus hidrologi yang akan diterapkan pada peserta didik kelas V sekolah dasar. Desain penelitian ini dikembangkan oleh Borg \& Gall yang dimodifikasi oleh Sugiyono (2015: 409).

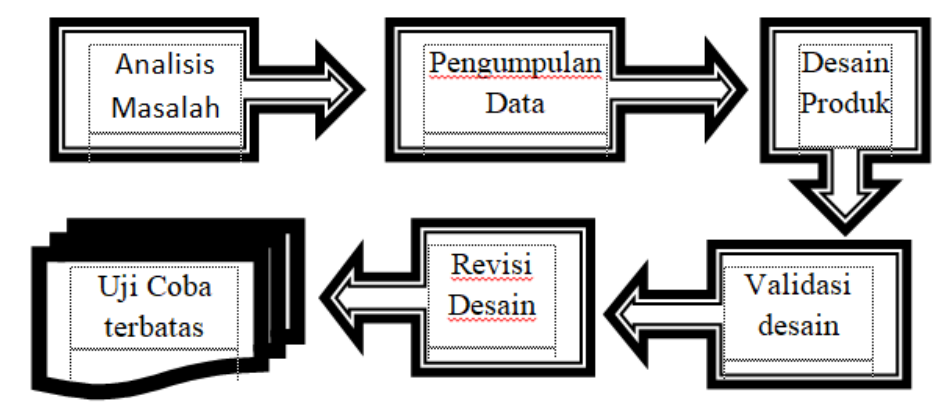

Gambar 1. Alur Modifikasi Metode R\&D Sugiyono (2015 :409)

Gambar di atas menjelaskan prosedur yang dilaksanakan dalam mengembangkan media pembelajaran panggung siklus hidrologi. Berdasarkan gambar tersebut, langkah-langkah 
penelitian meliputi enam langkah, yaitu analisis masalah, pengumpulan data, desain produk, validasi desain, revisi desain dan uji coba produk.

Populasi pada penelitian ini awalnya adalah seluruh siswa kelas V di SDN Teras 1 yaitu sebanyak 25 peserta didik. Pada penelitian ini terdapat perubahan teknis karena dampak dari kejadian luar biasa (KLB COVID19) yang menggemparkan dunia termasuk Indonesia dan dikarenakan keadaan yang tidak memungkinkan untuk proses belajar mengajar seperti sediakala, oleh sebab itu UPTD Pendidikan setempat membuat kebijakan yaitu siswa agar tetap melaksanakan proses belajar dan mengajar bersama wali kelas di sekolah namun tetap memperhatikan protokol kesehatan. Setiap hari sekolah hanya mengizinkan dalam satu hari untuk satu kelas atau mengikuti tanggal untuk masuk sekolah, dan satu kelas menjadi 15 siswa dikarenakan adanya social distancing yang merupakan bagian dari protokol kesehatan.

Teknik pengumpulan data pada penelitian ini menggunakan wawancara tidak terstruktur, angket (uji ahli dan respons peserta didik), dan dokumentasi. Wawancara menurut Sugiyono (2012:57) wawancara ialah proses untuk menemukan informasi yang akurat melalui tanya jawab dengan bertatap muka antara pewawancara dan subyek dengan memakai panduan wawancara. Peneliti melakukan wawancara kepada pihak sekolah yaitu Guru Kelas V SD Negeri Teras 1 Sutrisno Hadi (Sugiyono, 2012:145) menyatakan bahwa, observasi ialah suatu proses yang bertautan, suatu proses yang terdiri dari berbagai proses biologis dan psikologi Peneliti melakukan observasi awal di SDN Teras V untuk mengetahui permasalahan pembelajaran yang muncul di kelas di mana hasil observasi dicatat menjadi lembar analisis kebutuhan. Sedangkan angket ialah suatu cara pengumpulan data secara tidak langsung (peneliti tidak langsung bertanya-jawab dengan responden). Dalam kegiatan ini peneliti memberikan pernyataan yang akan dijawab oleh siswa sebagai responden (Sudaryono, 2011:181).

Angket dalam penelitian ini digunakan untuk penilaian pengembangan dan kelayakan media pembelajaran, diantaranya angket uji ahli media, uji ahli materi, uji ahli bahasa, dan angket respons siswa. Dokumentasi digunakan untuk memperkuat data yang diperoleh dari hasil angket atau kuisioner dan wawancara.

Instrumen yang digunakan untuk mengumpulkan data pada penilitian ini, yaitu a) wawancara guru kelas V SD Negeri Teras 1 terkait analisis kebutuhan media pembelajaran panggung siklus hidrologi, b) angket validasi uji ahli untuk mengukur kelayakan pada media pembelajaran panggung siklus hidrologi, c) Angket respons peserta didik digunakan untuk mengetahui tanggapan siswa terhadap media pembelajaran panggung siklus hidrologi.

Analisis data angket uji ahli dilakukan berdasarkan kriteria indikator keberhasilan yaitu memperoleh kriteria minimal 61-80\%. Skor yang diperoleh dari penilaian kelayakan oleh uji ahli akan dihitung dengan menggunakan rumus sebagai berikut:

$\mathrm{NP}=\frac{R}{S M} \times 100 \%$

(Purwanto , 2013:102)

NP adalah nilai rata-rata dalam persen (\%) yang diberi, $\mathrm{R}$ adalah skor yang diperoleh dari setiap aspek, dan SM adalah skor maksimum dari seluruh aspek. Nilai yang diperoleh kemudian di interpretasikan sesuai dengan kriteria yang telah ditentukan sebagai berikut:

Tabel 1. Kriteria Kelayakan Media

\begin{tabular}{ll}
\hline Presentasi Pencapaian & Kategori Kelayakan \\
\hline $81 \%-100 \%$ & Sangat layak \\
$61 \%-80 \%$ & Layak \\
$41 \%-60 \%$ & Cukup layak \\
$21 \%-40 \%$ & Kurang Layak \\
$0 \%-20 \%$ & Tidak layak \\
\hline
\end{tabular}

(Sumber: modifikasi Purwanto, 2013: 103) 


\section{HASIL DAN PEMBAHASAN}

Hasil penelitian dan pengembangan ini media pembelajaran panggung siklus hidrologi ini dilakukan berdasarkan prosedur pengembangan menurut Borg dan Gall yang telah dimodifikasi oleh Sugiyono. Pemilihan prosedur pengembangan ini telah ditetapkan, yaitu melakukan analisis masalah, pengumpulan data, desain produk, validasi desain produk, revisi desain, dan uji coba produk. Pada tahap analisis masalah peneliti melakukan analisis kurikulum, analisis materi dan analisis kebutuhan media pembelajaran panggung siklus hidrologi.

Analisis kebutuhan dilakukan dengan melakukan wawancara tidak terstruktur kepada guru dan observasi saat guru mengajar. Berdasarkan hasil wawancara tidak terstruktur dan observasi dengan wali kelas $\mathrm{V}$, permasalahan dalam proses pembelajaran di kelas tersebut yaitu kurangnya memahami konsep siklus air atau siklus hidrologi dan pada keterangannya bahwa selama ini pembelajaran dan materi tersebut masih masih terpaku pada buku dan kurang memanfaatkan lingkungan sekitar maupun benda-benda yang dapat disajikan sebagai media pembelajaran. Selain itu, metode yang diterapkan oleh guru juga belum bervariasi masih dengan alur monoton, guru juga belum bisa memanfaatkan alat peraga yang dapat dikreasikan, alat peraga yang guru perlihatkan hanya gambar biasa dan tidak berbentuk seperti nyata. Hal ini dikarenakan kurangnya kemampuan guru untuk mengembangkan proses pembelajaran. Keadaan tersebut mengakibatkan kurangnya pemahaman peserta didik terhadap pembelajaran daur air dan kurangnya aktivitas peserta didik pada saat pembelajaran.

Selanjutnya untuk analisis materi, peneliti melakukan analisis KI dan KD pada buku Tema 8 SubTema 1 Pembelajaran ke 1 . Peneliti menganalisis materi sekaligus menganalisis kebutuhan untuk mencari solusi yang tepat terhadap materi pembelajaran tersebut. Setelah peneliti menganalisis, peneliti mengambil materi siklus air atau daur air karena materi ini memerlukan pengembangan media pembelajaran yang dapat menarik perhatian peserta didik. Media pembelajaran yang digunakan adalah media panggung siklus hidrologi. Pengembangan media pembelajaran ini diharapkan dapat menciptakan kegiatan pembelajaran yang bermakna sehingga peserta didik mampu memahami pembelajaran IPA serta memudahkan guru untuk mencapai tujuan pembelajaran.

Pada proses pengembangan produk ini yang dilakukan adalah mempersiapkan alat dan bahan yang akan digunakan, bentuk media, ukuran media, dan bagaimana cara pembuatannya dan yang terakhir mencari materi yang sesuai untuk diajarkan dengan media. Adapun proses pembuatan, alat dan bahan yang digunakan sebagai berikut:

1) Pada tahap awal pembuatan media pembelajaran panggung siklus hidrologi adalah proses mempersiapkan alat dan bahan yang akan digunakan dalam pembuatan media pembelajaran tersebut. Adapun alat dan bahan yang digunakan yaitu gunting, cutter, alat lem tembak beserta isinya, mist maker (mesin pembuat kabut aquarium), pompa mini aquarium beserta adaptor, dua buah led lamp motor berwarna putih, saklar beserta rangkaian listrik, kotak kayu, dua lembar akrilik ukuran $60 \mathrm{~cm} \times 100 \mathrm{~cm}$ (bahan kaca yang lebih ringan $50 \%$ dari bahan kaca yang asli), nampan biru, miniatur pohon, miniatur hewan yang hidup di laut dan di darat, double tipe, dakron, kain yang sudah tidak terpakai, sterofoam jumbo satu lembar, cat semprot berwarna biru langit, cat coklat dan hijau, magnet mainan, lis alumunium, lem power glue, emoji, pelepah pisang, semen putih dan gypsum masingmasing $1 \mathrm{~kg}$.

2) Pada tahap proses ini, menggambarkan bagaimana proses pembuatan media pembelajaran panggung siklus hidrologi. Dalam proses pembuatan media pembelajaran panggung siklus hidrologi terbagi ke dalam beberapa tahap. Tahap pertama adalah dengan membuat gambar konsep media yang akan dibuat, tahap selanjutnya adalah proses pemotongan akrilik sesuai dengan ukuran kebutuhan dan perekatan lem pada akrilik agar dapat segera merekat dengan sempurna setelah itu agar tahan lama dan tidak rusak, pada sudut akrilik ditambahkan sebuah list alumunium 


\section{PRIMARY : JURNAL PENDIDIKAN GURU SEKOLAH DASAR \\ VOLUME 9 NOMOR 6 DESEMBER 2020 \\ ISSN: 2303-1514 | E-ISSN: 2598-5949 \\ DOI : http://dx.doi.org/10.33578/jpfkip.v9i6.8049 \\ https://primary.ejournal.unri.ac.id/index.php/JPFKIP}

gunanya sebagai penguat agar sudut-sudut akrilik berbentuk persegi ini tidak rusak. Adapun secara rinci proses pembuatannya sebagai berikut:

a) Potong akrilik $60 \mathrm{~cm} \mathrm{x} 100 \mathrm{~cm}$ seperti gambar di bawah ini.

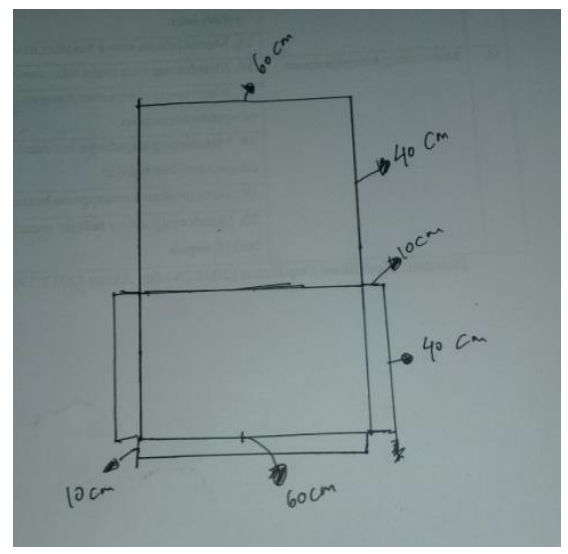

Gambar 2. Konsep Awal Rancangan Panggung Siklus Hidrologi

b) Selanjutnya membuat lubang pada akrilik menggunakan mesin gerinda pada letak tertentu untuk penempatan led lamp sebagai matahari dan lubang untuk keluar-masuk selang air dari mesin pump mini sebagai siklus air hujan.

c) Setelah itu, penyemprotan cat semprot berwarna biru langit pada background panggung siklus hidrologi yang berdiri tegak.

d) Selanjutnya membuat gunung menggunakan adonan semen putih dan gypsum, kain dimasukkan ke dalam adonan campuran dari semen putih dan gypsum kemudian setelah adonan tersebut benar-benar meresap pada kain, angkat dan bentukkan menyerupai gunung (sebelumnya membuat kaki penyangga untuk kain menggunakan pasak bambu yang dikondisikan), tunggu sampai benar-benar kering. Di lain sisi, letak bawah gunung tersebut sudah dilapisi dua lapis sterofoam ukuran $10 \mathrm{~cm}$ x $30 \mathrm{~cm}$, dan sampingnya terdapat nampan biru tua yang diposisikan sebagai laut.

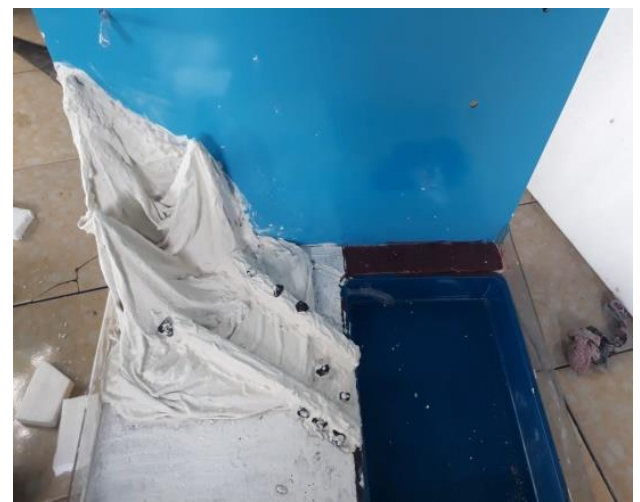

Gambar 3. Pembuatan Gunung dengan Semen Putih

e) Selanjutnya membuat box berisi rangkaian listrik untuk led lamp dan pump mini yang akan disajikan menggunakan saklar, box ini berukuran $15 \mathrm{~cm}$ x $10 \mathrm{~cm}$ berbahan triplek tipis berdiameter $5 \mathrm{~mm}$, perekat yang digunakan yaitu power glue. 


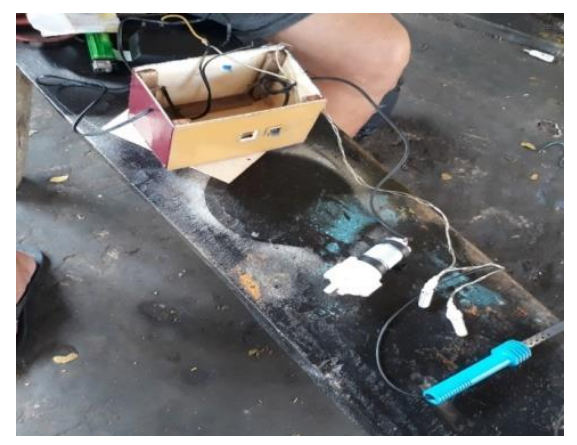

Gambar 4. Perakitan Box untuk Saklar Led Lamp dan Pump Mini

f) Gunung yang telah mengering kemudian diberikan warna dengan cat warna hijau, sungai disemprot dengan cat semprot berwarna biru, warna dasar dari lapisan di bawah gunung diwarnai dengan warna coklat sebagai tanah.

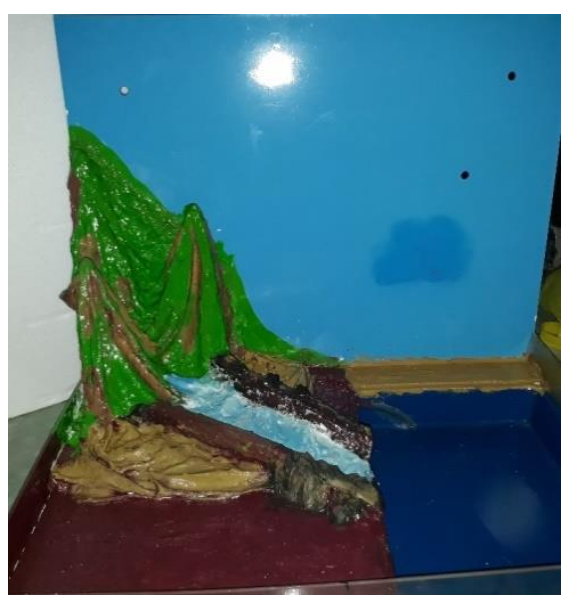

Gambar 5. Pemberian Warna Pada Gunung

g) Selanjutnya setelah tersusun rapih sesuai dengan bentuk dan letak gunung, air sungai dan laut. Kemudian susun miniatur- miniatur yang sudah dipersiapkan, seperti miniatur rumah-rumahan berbahan pelepah pisang dan sterofoam, miniatur pepohonan, miniatur hewan yang ada di darat dan di laut sesuai dengan letak yang sudah ditentukan. 


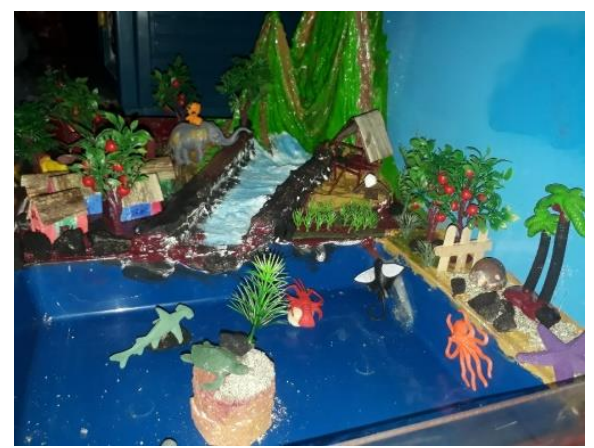

\section{Gambar 6. Penyusunan Miniatur-miniatur Pohon, Rumah, dan Hewan-hewan}

h) Tahap ini adalah tahap terakhir. Pada tahap ini melakukan penempelan keterangan dari bahan kertas yang dilaminating, keterangan tersebut berupa gambar panah, kata evaporasi transpirasi kondensasi presipitasi run off dan infiltrasi.

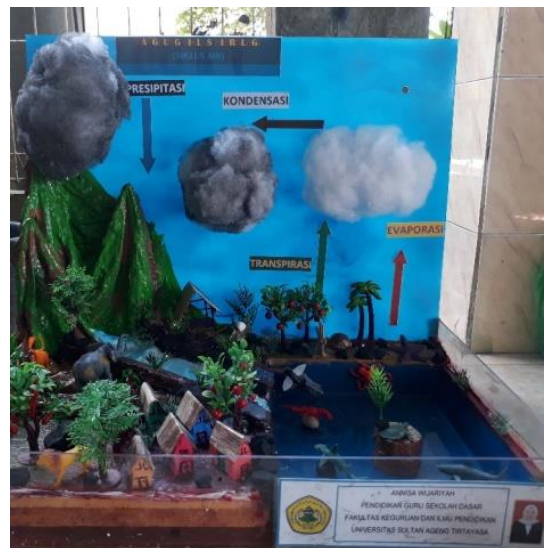

\section{Gambar 7. Kenampakan Seluruh Isi Media}

Produk yang telah dikembangkan harus melewati tahapan validasi (uji ahli) terlebih dahulu sebelum diuji coba ke lapangan. Validasi dilakukan oleh dua ahli media, dua bahasa, dan dua ahli materi yang berkompeten. Tabel di bawah ini merupakan hasil dari angket uji ahli dalam penelitian.

Tabel 2. Hasil Uji Ahli Media

\begin{tabular}{|c|c|c|c|}
\hline Aspek Penilaian & Ahli Media I & Ahli Media II & Total \\
\hline $\begin{array}{l}\text { Kesesuaian media dengan tujuan } \\
\text { pembelajaran. } \\
\text { Kesesuaian media dengan karakteristik siswa. } \\
\text { Dapat menjadi sumber belajar. Efesiensi dan } \\
\text { efektifitas pemanfaatan media. Kemampuan } \\
\text { media dalam mengembangkan sarana } \\
\text { pembelajaran yang menyenangkan. } \\
\text { Kemampuan bagi pembelajaran. } \\
\text { Kualitas media. }\end{array}$ & 101 & 100 & 201 \\
\hline Presentase Nilai $(\%)$ & $91.81 \%$ & $90.90 \%$ & \\
\hline Rata-Rata & & $91.36 \%$ & \\
\hline Kriteria & & Sangat Layak & \\
\hline
\end{tabular}


Berdasarkan tabel data penilaian uji ahli media di atas, didapatkan jumlah skor dari ahli media I sebesar 101 dari jumlah skor maksimal 110 dengan persentase sebesar $91.81 \%$. Adapun jumlah skor dari ahli media II sebesar 100 dari jumlah skor maksimal 110 dengan persentase sebesar $90.90 \%$, nilai tersebut masuk pada kriteria "sangat layak" berdasarkan kategori interpretasi menurut Purwanto (2013: 103). Media dianggap dapat digunakan dengan revisi untuk menyempurnakan media yang dikembangkan peneliti.

Tabel 3. Hasil Uji Ahli Materi

\begin{tabular}{|c|c|c|c|}
\hline Aspek Penilaian & $\begin{array}{c}\text { Ahli Materi } \\
\text { I }\end{array}$ & $\begin{array}{c}\text { Ahli } \\
\text { Materi II } \\
\end{array}$ & Total \\
\hline $\begin{array}{l}\text { Relevansi materi } \\
\text { Keakuratan materi } \\
\text { Kemutakhiran materi } \\
\text { Mendorong keingintahuan }\end{array}$ & 92 & 94 & 186 \\
\hline Presentase Nilai (\%) & $92 \%$ & $94 \%$ & \\
\hline Rata-Rata & \multicolumn{2}{|l|}{$93 \%$} & \\
\hline Kriteria & \multicolumn{2}{|c|}{ Sangat Layak } & \\
\hline
\end{tabular}

Berdasarkan tabel data penilaian uji ahli media di atas, didapatkan jumlah skor dari ahli materi I sebesar 92 dari jumlah skor maksimal 100 dengan persentase sebesar 92\%. Adapun jumlah skor dari ahli materi II sebesar 94 dari jumlah skor maksimal 100 dengan persentase sebesar 94\%, nilai tersebut masuk pada kriteria "sangat layak" berdasarkan kategori interpretasi menurut
Purwanto (2013: 103). Dengan demikian, media pembelajaran panggung siklus hidrologi yang dibuat sudah cukup memenuhi aspek kelayakan materi karena berisi komponen bentuk yang sesuai dengan materi. Media pembelajaran panggung siklus hidrologi sudah layak digunakan dan dapat berlanjut ke tahap berikutnya.

Tabel 4. Hasil Uji Ahli Pendidikan

\begin{tabular}{lccc}
\multicolumn{1}{c}{ Aspek Penilaian } & $\begin{array}{c}\text { Ahli } \\
\text { Pendidikan I }\end{array}$ & $\begin{array}{c}\text { Ahli } \\
\text { Pendidikan II }\end{array}$ & Total \\
\hline $\begin{array}{l}\text { Aspek kelayakan isi/ materi } \\
\begin{array}{l}\text { Aspek kelayakan penyajian tampilan } \\
\text { Aspek penilaian bahasa }\end{array}\end{array}$ & 48 & 45 & 93 \\
\hline Presentase Nilai (\%) & & $\mathbf{9 0 \%}$ & \\
\hline Rata-Rata & $\mathbf{9 6 \%}$ & \multicolumn{2}{c}{$\mathbf{9 3 \%}$} \\
\hline Kriteria & \multicolumn{2}{c}{ Sangat Layak } \\
\hline
\end{tabular}

Berdasarkan tabel data penilaian uji ahli media di atas, didapatkan jumlah skor dari ahli pendidikan I sebesar 48 dari jumlah skor maksimal 50 dengan persentase sebesar $96 \%$. Adapun jumlah skor dari ahli materi II sebesar 45 dari jumlah skor maksimal 50 dengan persentase sebesar $90 \%$, nilai tersebut masuk pada kriteria "sangat layak" berdasarkan kategori interpretasi menurut
Purwanto (2013: 103). Dengan demikian, media pembelajaran panggung siklus hidrologi yang dibuat sudah cukup memenuhi aspek kelayakan pendidikan karena berisi komponen bentuk yang sesuai dengan materi. Media pembelajaran panggung siklus hidrologi sudah layak digunakan dan dapat berlanjut ke tahap berikutnya. 
Tabel 5. Hasil Respons Peserta Didik

\begin{tabular}{lllll}
\hline Aspek Penilaian & $\begin{array}{l}\text { Jumlah } \\
\text { Butir }\end{array}$ & $\begin{array}{l}\text { Jumlah } \\
\text { Skor }\end{array}$ & $\begin{array}{l}\text { Jumlah } \\
\text { skor ideal }\end{array}$ & Persentase \\
\hline Tampilan & 4 & 274 & 300 & $91 \%$ \\
Ketertarikan & 4 & 266 & 300 & $88 \%$ \\
Kemanfaatan & 2 & 128 & 150 & $85 \%$ \\
Jumlah & $\mathbf{1 0}$ & $\mathbf{6 6 8}$ & $\mathbf{7 5 0}$ & $\mathbf{2 6 4 \%}$ \\
\hline Rata-rata & & & & $\mathbf{8 9 \%}$ \\
\hline Kategori & & & & Sangat Layak \\
\hline
\end{tabular}

Berdasarkan hasil analisis data angket respons siswa di atas dapat dinyatakan bahwa media media pembelajaran panggung siklus hidrologi yang telah diuji cobakan mendapatkan persentase sebesar $89 \%$ masuk kategori sangat baik.

Berdasarkan beberapa penilaian dari uji ahli di atas, hasil penggabungan ahli media yakni mencapai persentase $91.36 \%$ dari skor maksimal penilaian yakni $100 \%$ dengan kategori "Sangat Layak". Kedua tim ahli media menyatakan bahwa media pembelajaran panggung siklus hidrologi ini menarik dan menumbuhkan semangat siswa dalam belajar, membuat pembelajaran lebih konkret, dan sangat berperan penting dalam pembelajaran IPA dengan materi siklus air di kelas V. hasil tersebut sesuai dengan penelitian yang telah dilakukan oleh Septi Kiswandari (5(10) 970-975) pada tahun 2015 yang berjudul "Pengembangan Media Pembelajaran Diorama Daur Air Pada Mata Pelajaran IPA Kelas V SD" Penelitian tersebut juga diterapkan untuk peserta didik kelas $\mathrm{V}$ dan menyatakan bahwa media tersebut sudah cukup efektif untuk menarik minat siswa dll., dalam pembelajaran. Sepadan dengan yang dikemukakan oleh Kochhar (2008:210). Alat peraga dapat memperkuat pembelajaran, antara lain : Membantu siswa mengenal pengetahuan secara langsung, menunjang kata terucap, membuat lebih nyata, jelas, menarik, dan seperti hidup, membantu mengembangkan kepekaan terhadap waktu dan tempat, mengembangkan kepekaan terhadap hubungan sebab akibat, membantu guru mengembangkan bahan pembelajarannya, menunjang bahan buku pelajaran, membantu pembelajaran permanen, menambah kesenangan dan minat pada pembelajaran.
Hasil penggabungan penilaian dari ahli materi mencapai persentase $93 \%$ dari skor maksimal penilaian yakni $100 \%$ dengan kategori "Sangat Layak". Kedua tim ahli materi menyatakan bahwa media pembelajaran sudah baik, memuat materi dengan cukup jelas dan unik, dapat memotivasi siswa dalam belajar siklus air dan cukup membuat siswa tumbuh rasa ingintahunya. Hasil tersebut diperkuat oleh pendapat Daryanto (2010:29), bahwasannya media pembelajaran diorama mempunyai kelebihan, berikut ini kelebihanya: memberikan pengalaman secara langsung, penyajian secara konkret dan menghindari verbalisme, dapat menunjukkan objek secara utuh baik konstruksi maupun cara kerjanya, dapat memperlihatkan struktur organisasi secara jelas, dapat menunjukkan alur suatu proses secara jelas.

Hasil penggabungan penilaian dari ahli pendidikan mencapai persentase $93 \%$ dari skor maksimal yakni 100\% dengan kategori "Sangat Layak". Kedua tim ahli menyatakan media pembelajaran sudah bisa digunakan dengan revisi, dalam media pembelajaran mengandung nilai keindahan yang konkret, siswa yakin akan keindahan ciptaan tuhan, menumbuhkan sikap ilmiah dalam menganalisis apa yanag mereka lihat. Hasil tersebut mempunyai persamaan dan dapat diperkuat oleh pendapat Depdiknas (2003:2) khusus fungsi dan tujuan IPA berdasarkan kurikulum berbasis kompetensi, sebagai berikut : menanamkan keyakinan terhadap Tuhan Yang Maha Esa, mengembangkan keterampilan, sikap dan nilai ilmiah, mempersiapkan sisa menjadi warga negara yang melek sains dan teknologi, menguasai konsep sains untuk bekal hidup di masyarakat dan melanjutkan pendidikan ke jenjang yang lebih tinggi. Dalam Tritanto (2010:143). 


\section{SIMPULAN DAN REKOMENDASI}

Penelitian ini telah menghasilkan produk berupa media pembelajran panggung siklus hidrologi di kelas V SD. Media pembelajaran panggung siklus hidrologi layak digunakan sebagai alat peraga pada mata pelajaran IPA materi siklus air di kelas $\mathrm{V}$ sekolah dasar dengan memperoleh hasil penilaian mencapai persentase $91 \%$ dari dua ahli media, 91\% dari dua ahli materi, dan $93 \%$ dari dua ahli materi. Tingkat kelayakan buku cerita bergambar dwibahasa memperoleh nilai rata-rata keseluruhan validasi ahli sebesar $92 \%$ yang masuk dalam kategori "Sangat Layak". Respons peserta didik terhadap media pembelajaran panggung siklus hidrologi pada mata pelajaran IPA di kelas V sekolah dasar pada uji coba lapangan yang melibatkan 15 siswa memperoleh persentase 89\% yang termasuk dalam kategori "Sangat Layak".

\section{DAFTAR PUSTAKA}

Basri, H. \& Rusdiana. (2015). Manajemen Pendidikan \& Pelatihan. Jakarta: Pustaka Setia.

Daryanto. (2010). Media Pembelajaran. Yogyakarta: Gava Media.

Indriana, D. (2011). Ragam Alat Bantu Media Pengajaran. Jakarta: PT. Diva Press.

Kiswandari, S. (2016). Pengembangan Media Pembelajaran Diorama Daur Air Pada Mata Pelajaran IPA Kelas V SD. Jurnal Elektronik Mahasiswa Prodi PGSD Universitas Negeri Yogyakarta (BASIC EDUCATION), 5 (10) 970-975).

Kochhar, S. K. (2008). Pembelajaran . Jakarta: Gramedia Widiasarana.

Kustadi, C. \& Sutjipto, B. (2011). Media Pembelajaran. Jakarta: Ghalia Indonesia.

Prastowo, A. (2015). Panduan Kreatif Membuat Bahan Ajar Inovatif. Yogyakarta: Diva Press.

Purwanto. (2010). Evaluasi Hasil Belajar. Yogyakarta: Pustaka Pengajar.

Sadiman, A. (2011). Media Pendidikan Pengertian, Pengembangan, dan Pemanfaatannya. Jakarta: PT Graha Grafindo Persada.

Sanaky, H. (2015). Media Pembelajaran InteraktifInovatif. Yogyakarta: Kaukaba Dipantara.
Berdasarkan hasil penelitian dan kesimpulan di atas, maka peneliti mengajukan saran untuk meningkatkan kualitas media pembelajaran cerita bergambar dwibahasa, diantaranya: (1) media pembelajaran panggung siklus hidrologi dapat menjadi alat peraga dalam pembelajaran IPA, (2) media pembelajaran panggung siklus hidrologi dapat menjadi alternatif bagi guru agar menjadi sarana prasarana alat peraga di sekolah dasar sehingga pembelajaran lebih efektif dan efisien, (3) Sebaiknya mempertimbangkan biaya bahan-bahan dan pembuatanagar lebih mudah dan murah serta untuk menghindari pemborosan biaya, tenaga, dan waktu penelitian.

Sudjana, N. \& Rivai, A. (2013). Media Pengajaran. Bandung: Sinar Baru.

Sugiyono. (2012). Metode Penelitian Kombinasi (Mixed Methods). Bandung:Alfabeta.

(2015). Metode Penelitian Pendidikan. Bandung: Alfabeta.

(2013). Metode Penelitian Kuantitatif, Kualitatif, dan R\&D. Bandung: Alfabeta.

Tritanto. (2010). Model Pembeljaran Terpadu. Jakarta: Bumi Aksara.

Wisudawati, A.W. \& Sulistyowati, E. (2014). Metodologi Pembelajaran IPA. Jakarta: Bumi Aksara. 